\title{
First nest description of the Azure-shouldered Tanager (Thraupis cyanoptera, Thraupidae)
}

\author{
Paulo Victor Queijo Zima ${ }^{1}$, Daniel Fernandes Perrella ${ }^{1} \&$ Mercival Roberto Francisco $^{1,2,3}$ \\ Programa de Pós-Graduação em Ecologia e Recursos Naturais, Universidade Federal de São Carlos, São Carlos, SP, Brazil. \\ Departamento de Ciências Ambientais, Universidade Federal de São Carlos, Sorocaba, SP, Brazil. \\ 3 Corresponding author: mercival@ufscar.br
}

Received on 07 December 2018. Accepted on 04 July 2019.

\begin{abstract}
The genus Thraupis represents the typical tanagers, and despite the commonness of some species their reproductive aspects are poorly documented. Here we provide the first description of nests and nestlings of the Azure-shouldered Tanager, Thraupis cyanoptera, and we provide additional information on eggs. We found three active nests at Carlos Botelho State Park, southeastern Brazil, in September and October 2014, and in November 2016. The nests were built within large tangles of bromeliads, 4.1-5.2 m above ground. They were shallow bottom-supported cups, composed mainly of elongated stripes of dry bromeliad leaves. Eggs were subeliptical, with white background color and small brown spots and blotches evenly distributed throughout the surface. Nestlings had pink skin and gray down, with ocher bill and white swollen flanges. Although more forest-dwelling than other congeners, the Azure-shouldered Tanager seems to tolerate some habitat disturbance, as nests were observed in clearings.
\end{abstract}

KEY-WORDS: Aves, breeding biology, nesting biology, reproduction, Tangara.

The genus Thraupis (Thraupidae, subfamily Thraupinae) is composed of seven species of small Neotropical passerines that represent the typical tanagers (Burns et al. 2016). They are characterized by discrete plumages, predominantly bluish and olive, and absence of sexual dimorphism in most species (Ridgely \& Tudor 1989). They inhabit humid forests or wooded areas, various types of open areas, and even urban environments (Ridgely \& Tudor 1989, Hilty 2019). Despite the commonness of some taxa, reproductive aspects are generally poorly documented, although nests and eggs have been welldescribed except for the Azure-shouldered Tanager, Thraupis cyanoptera, the Golden-chevroned Tanager, Thraupis ornata, and the Glaucous Tanager, Thraupis glaucocolpa (Hilty 2019).

The Azure-shouldered Tanager is endemic to the Atlantic Forest of southeastern Brazil, and can be found from the slopes of Serra do Mar to humid montane forests from southeast Bahia, Minas Gerais and Espírito Santo states, southern to Rio Grande do Sul (Ridgely \& Tudor 1989, Hilty 2019). It is more forest-dwelling than some congeners, occurring in forest canopy, but also in borders and secondary growth (Ridgely \& Tudor 1989, Naka et al. 2002). The only information on the reproductive biology of this species is the description of two eggs as being pale blue with a few round spots of very dark purple color (Ogilvie-Grant 1912), and a mention by Kirwan (2009) that "a nest was being built on a bromeliad epiphyte in a tree about six meters high, to which parents carried grass, and fine and large materials". Here we present the first description of nests and nestlings of the Azure-shouldered Tanager, and we provide additional egg information.

This study was carried out at Carlos Botelho State Park (PECB) $\quad\left(24^{\circ} 06^{\prime} 55^{\prime \prime}-24^{\circ} 14^{\prime} 41^{\prime \prime S}\right.$; 47 4 $47^{\prime} 18^{\prime \prime}-$ $\left.48^{\circ} 07^{\prime} 17^{\prime \prime} \mathrm{W}\right)$, state of São Paulo, Brazil. The PECB has an area of 37,644 ha, between altitudes of $20-1000 \mathrm{~m}$ a.s.l., and vegetation cover is composed predominantly of primary Atlantic Forest. The average rainfall is 1676 $\mathrm{mm}$ and average temperature between $18^{\circ} \mathrm{C}$ and $20^{\circ} \mathrm{C}$ (Ferraz \& Varjabedian 1999). The region where the nests were found had an altitude of 714-837 $\mathrm{m}$ a.s.l., in an area in which the vegetation is classified as submontane rainforest (Oliveira-Filho \& Fontes 2000).

During 2014/2015 and 2016/2017 breeding seasons we located the nests of the Azure-shouldered Tanager following adult birds when they were carrying material for nest construction or food to attend nestlings (Martin \& Geupel 1993). When nests and eggs were found, measurements and photos were taken (Figs. $1 \&$ 2). Eggs and nests were measured with a metal caliper accurate to $0.1 \mathrm{~mm}$, and the eggs were weighed to the nearest $0.1 \mathrm{~g}$ using a spring scale. Nest architecture and eggs shape were classified according to Winkler (2004).

During two non-consecutive breeding seasons, we found three nests in the middle of the same large tangle of bromeliads. The epiphytes were agglomerated in the 
trunk of an approximately $12 \mathrm{~m}$ high three, only $6 \mathrm{~m}$ from one of the buildings of the Park's administrative

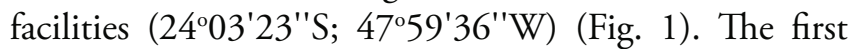
nest was found in 09 September 2014 in construction stage, and on 18 September it contained two eggs. The second nest was found on 18 October 2014 with two nestlings, and the third nest was found on 17 November 2016, with two nestlings in early developmental stage. The first nest was abandoned in incubation stage, and the fate of others nests is unknown.

Nests were shallow cups built mainly of elongated stripes of dry bromeliad leaves, and in a smaller amount other dry leaves. Slender elongated pieces of vines were used in nest rims, and incubatory chamber was lined with finer vegetal fibers, grass leaves, and in one nest black fungal hyphae (Fig. 2A). They were bottom-supported and were placed deep in the middle of the epiphyte tangle, where light exposition was minimal and where they were likely protected from rain. Measurements of the first nest were: outer diameter $15.4 \mathrm{~cm}$, inner diameter $6.7 \mathrm{~cm}$, depth $2.9 \mathrm{~cm}$, height $5.3 \mathrm{~cm}$, and it was $4.4 \mathrm{~m}$ above ground. The second nest had an outer diameter of 13.8 $\mathrm{cm}$, inner diameter of $7.2 \mathrm{~cm}$, depth of $4.0 \mathrm{~cm}$, height of $7.6 \mathrm{~cm}$, and it was $5.2 \mathrm{~m}$ above ground. The third nest was $4.13 \mathrm{~m}$ above the ground, and its measurements were not taken because it was partially destroyed about 20 days later, when we returned to collect the data. In $1 \mathrm{~h}$ focal observation during the construction stage of the first nest, adults brought nest materials five times, with both adults carrying and depositing nest materials. The eggs

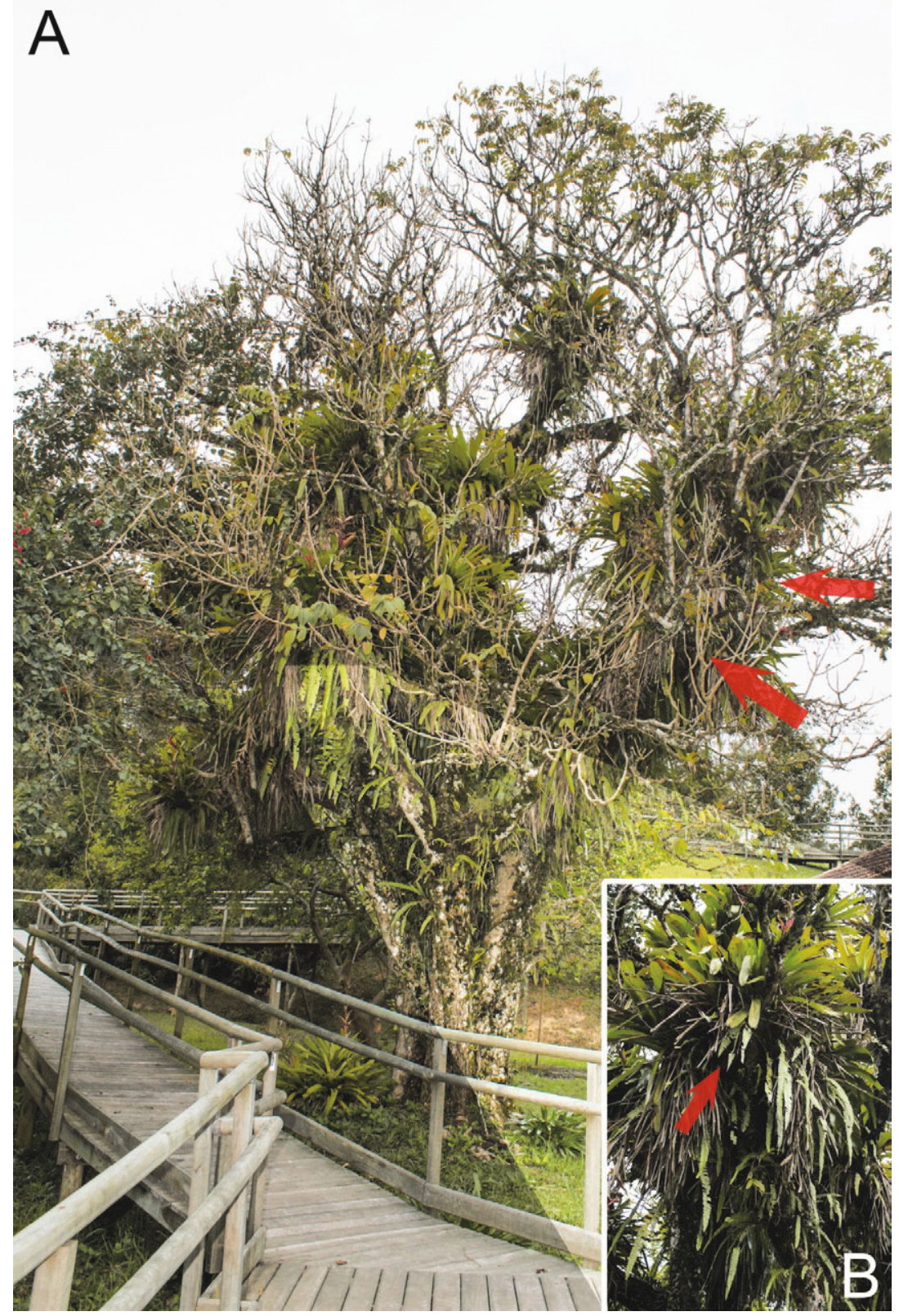

Figure 1. Nesting sites of the Azure-shouldered Tanager (Thraupis cyanoptera, Thraupidae) at Carlos Botelho State Park, state of São Paulo, Brazil. (A) Nesting tree and bromeliads overview; (B) detailed view of a nesting site within a large bromeliad tangle. Photo author: Daniel F. Perrella. 

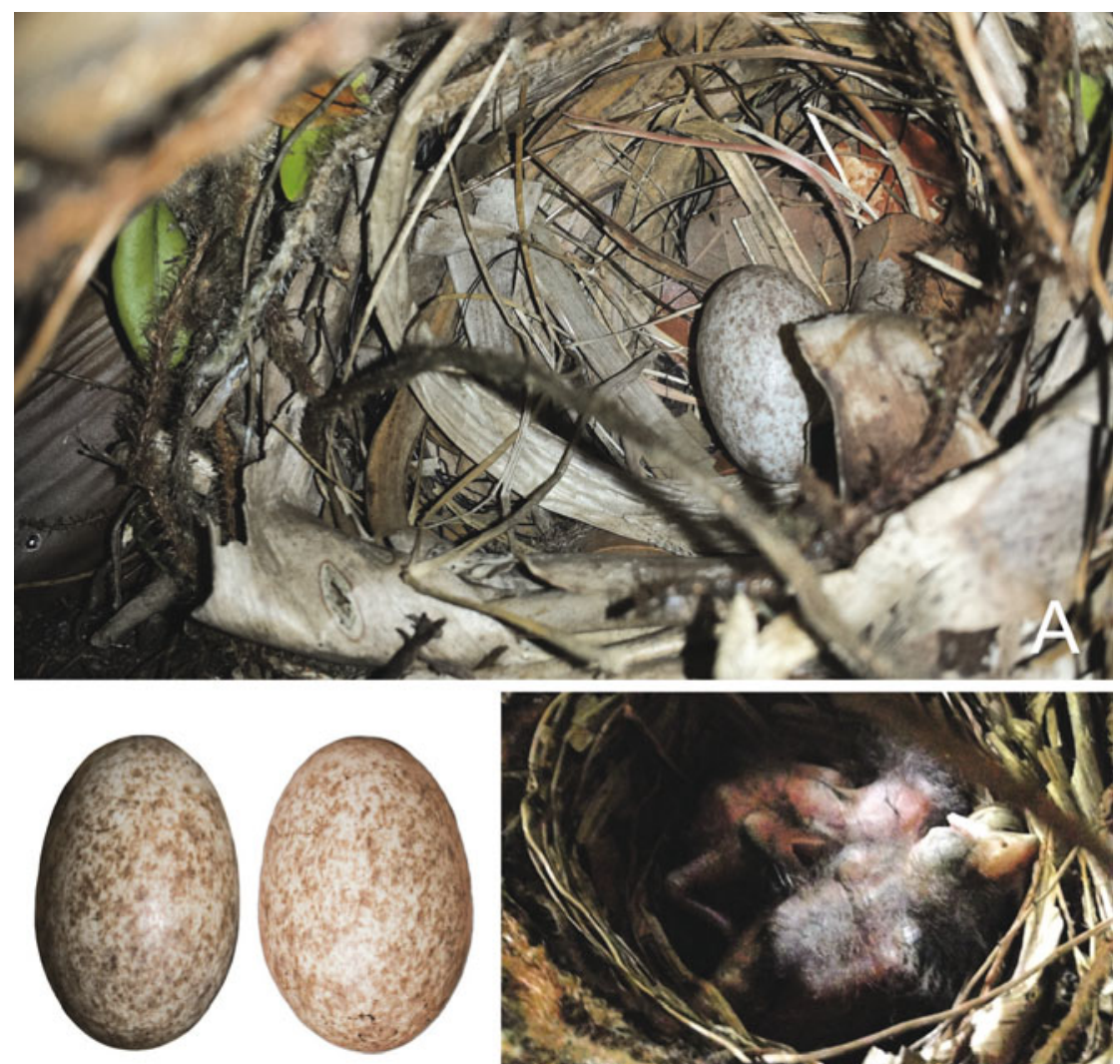

B

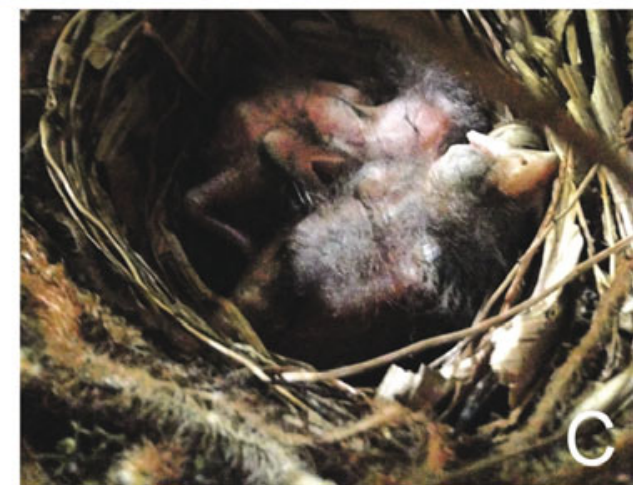

Figure 2. Nest, eggs and nestlings of the Azure-shouldered Tanager (Thraupis cyanoptera, Thraupidae). (A) Details on nest material and nest shape; $(\mathbf{B})$ eggs shape and markings; $(\mathbf{C})$ nestlings in early developmental stage. Nest and egg sizes are presented in the main text. Photo author: Daniel F. Perrella \& Michele V. Katayama.

were subeliptical with white background color and small brown spots and blotches that were evenly distributed throughout the egg surface (Fig. 2B). They measured $28.0 \times 18.6 \mathrm{~mm}$ and $29.9 \times 18.2 \mathrm{~mm}$, and both had mass of $4.5 \mathrm{~g}$. The nestlings had pink skin and gray down, with ocher bill and white swollen flanges (Fig. 2C).

The dates in which we found the nests of the Azureshouldered Tanager fall within the breeding season of other Thraupidae previously studied in southeastern Brazil, including the Burnished-buff Tanager, Tangara cayana (September-December, Marini et al. 2007), the Red-crested Finch, Coryphospingus cucullatus (OctoberFebruary, Zima \& Francisco 2016), and the Grasslandyellow Finch, Sicalis luteola (October-February, Freitas \& Francisco 2012). In all these cases, nesting activities started at the end of the dry season in the region.

The cup-shaped nests of the Azure-shouldered Tanager, with nest walls constructed mainly of elongated pieces of dry leaves followed the general pattern found for other congeners, i.e., the Palm Tanager, Thraupis palmarum (Mitchell 1957, Isler \& Isler 1999), the Blue-gray Tanager, Thraupis episcopus (Skutch 1954), the Yellow-winged Tanager, Thraupis abbas (Edwards \& Tashian 1959, Isler \& Isler 1999), and the Sayaca Tanager, Thraupis sayaca (Almeida et al. 2012, de la Peña 2016). However, available descriptions suggest that materials used in nest lining and other materials used in nest walls in smaller amounts can vary within the group, and also probably within species, as black fungal hyphaes were found in the incubatory chamber of only one of the three nests found. Notably, at least Blue-gray and Sayaca Tanagers use spider webs to bound nest material together (Skutch 1954, M.R.F., pers. obs.), which we did not observe for the Azure-shouldered Tanager.

The white egg background color and the high density of brown markings do not match the egg descriptions previously provided by Ogilvie-Grant (1912) that eggs were pale blue with a few round spots of very dark purple color. As we observed eggs from only one nest, it is to be confirmed if this incongruence represents possible intraspecific egg color variations. In the Sayaca Tanager, for instance, egg background color can indeed vary from white to bluish green (M.R.F., pers. obs.). Within the genus Thraupis relevant variations can also be found in nest placement. While we observed the nests of the Azure-shouldered Tanager inside bromeliads, the Palm Tanager often build nests in the basis of palm leaves (Mitchell 1957, Isler \& Isler 1999), and Blue-gray (Skutch 1954) and Yellow-winged Tanagers (Edwards \& Tashian 1959) can build their nests both in palm leaves or in bifurcations of shrubs or trees.

Although reported as more forest-dependent than 
other congeners (Ridgely \& Tudor 1989), the Azureshouldered Tanager seem to support some levels of habitat disturbance as nests were observed in anthropic clearings (present study) and even in urban areas from coastal cities (Kirwan 2009). We are unaware about how dependent the Azure-shouldered Tanager is from large bromeliads to build their nests, but available data suggest that keeping this type of vegetation may contribute with the persistence of this species in disturbed habitats.

\section{ACKNOWLEDGEMENTS}

The authors thank the Brazilian agency Fundação de Amparo à Pesquisa do Estado de São Paulo (FAPESP) for financial support (Project SISBIOTA networkTop predators 2010/52315-7). P.V.Q. Zima and D.F. Perrella received fellowships from Conselho Nacional de Desenvolvimento Cientifico e Tecnológico (CNPq). ICMBio (SISBIO \#30794-1, and \#55003-1) and the Ethic Committee on Animal Use of the Federal University of São Carlos (CEUA/UFSCAR) have authorized the research and have approved the methods, and Instituto Florestal do Estado de São Paulo (IF) (COTEC \#260108013.921/2011, and \#782/2016 D137/2016 TN) provided permits for fieldwork at Carlos Botelho State Park. We are also grateful Danilo da Costa Silva for the contribution with the preparation of images.

\section{REFERENCES}

Almeida S.M., Evangelista M.M. \& Silva E.J.A. 2012. Biologia da nidificação de aves no município de Porto Esperidião, Mato Grosso. Atualidades Ornitológicas 167: 51-56.

Burns K.J., Unitt P., \& Mason N.A. 2016. A genus-level classification of the family Thraupidae (Class Aves: Order Passerifomes). Zootaxa 4088: 329-354.

de la Peña M.R. 2016. Aves argentinas: descripción, comportamiento, reproducción y distribución (Mimidae a Passeridae). Comunicaciones del Museo Provincial de Ciencias Naturales "Florentino Ameghino": Nueva Serie 21: 88-99.

Edwards E.P. \& Tashian R.E. 1959. Avifauna of the Catemaco Basin of southern Veracruz, Mexico. Condor 61: 325-327.

Ferraz L.P.M. \& Varjabedian R. 1999. Evolução histórica da implantação e sintese das informaçôes disponiveis sobre o Parque Estadual Carlos Botelho. São Paulo: Secretaria do Meio Ambiente.

Freitas M.S. \& Francisco M.R. 2012. Nesting behavior of the Yellow Finch (Sicalis luteola) in southeastern Brazil. Ornitología Neotropical 23: 341-348.

Hilty S. 2019. Azure-shouldered Tanager (Tangara cyanoptera). In: del Hoyo J., Elliott A., Sargatal J., Christie D.A. \& de Juana E. (eds.). Handbook of the birds of the world alive. Barcelona: Lynx Editions. https://www.hbw.com/node/61637 (Access on 23 May 2019).

Isler M.F. \& Isler P.R. 1999. The tanagers: natural history, distribution, and identification. Washington: Smithsonian Institution Press.

Kirwan G.M. 2009. Notes on the breeding ecology and seasonality of some Brazilian birds. Revista Brasileira de Ornitologia 17: 121136.

Marini M.Â., Aguilar T.M., Andrade R.D., Leite L.O., Anciães M., Carvalho C.E.A., Duca C., Maldonado-Coelho M., Sebaio F. \& Gonçalves J. 2007. Biologia da nidificação de aves do sudeste de Minas Gerais, Brasil. Revista Brasileira de Ornitologia 15:367-376.

Martin T.E. \& Geupel G.R. 1993. Nest-monitoring plots: methods for locating nests and monitoring success. Journal of Field Ornithology 64: 507-519.

Mitchell M.H. 1957. Observations on birds of southeastern Brazil. Toronto: University of Toronto Press.

Naka L.N., Rodrigues M., Roos A.L. \& Azevedo M.A.G. 2002. Bird conservation on Santa Catarina Island, southern Brazil. Bird Conservation International 12: 123-150.

Ogilvie-Grant W.R. 1912. Catalogue of the collection of birds' eggs in the British Museum (Natural History), v. 5. London: Trustees of the British Museum (Natural History).

Oliveira-Filho A.T. \& Fontes M.A.L. 2000. Patterns of floristic differentiation among Atlantic Forests in southeastern Brazil, and the influence of climate. Biotropica 32: 793-810.

Ridgely R.S. \& Tudor G. 1989. The birds of South America (the Oscine passerines), v. 1. Austin: University of Texas Press.

Skutch A.F. 1954. Life histories of Central American birds I: families Fringillidae, Thraupidae, Icteridae, Parulidae and Coerebidae. Pacific Coast Avifauna 31: 1-446.

Winkler D.W. 2004. Nests, eggs, and young: breeding biology of birds, p. 8.1-8.152. In: Podulka S., Rohrbaugh-Jr. R.W. \& Bonney R. (eds.). Handbook of bird biology. Ithaca: Princeton University Press.

Zima P.V.Q. \& Francisco M.R. 2016. Reproductive behavior of the Red-crested Finch Coryphospingus cucullatus (Aves: Thraupidae) in southeastern Brazil. Zoologia 33: e20160071.

Associate Editor: Lilian T. Manica. 